\title{
PENGARAHAN PEMBELAJARAN IPA MENGGUNAKAN METODE DEMONTRASI DI SD NEGERI CIPOROS 03 KARANGPUCUNG, KABUPATEN CILACAP
}

\author{
Hesti Nurlaeli \\ STKIP Darussalam Cilacap \\ E-mail: hestivano17@gmail.com
}

\begin{abstract}
ABSTRAK. Pendidikan adalah pembelajaran pengetahuan, keterampilan, dan kebiasaan sekelompok orang yang diturunkan dari satu generasi ke generasi beirkutnya melalui pengajaran, pelatihan, atau penelitian. Pendidikan didukung dengan namanya kurikulum, pada kurikulum 2013, mata pelajaran tidak lagi terpisahpisah, namun sudah terintegrasi menjadi satu, materi pelajaran dijadikan tema-tema, dan dari tema itu menjaid subtema. Dalam pelajaran IPA di SD, mulai dipelajari di kelas atas (kelas 4-6), pendidik diharapkan lebih inovasi dan kreatif dalam mengajar, apalagi dalam pelajaran IPA dimana, IPA itu pelajaran alam yang kalau hanya diberikan secara ceramah, pemberian tugas dan latihan saja maka akan kurang bermakna dan kurang membuat peserta didik memahami pelajaran IPA tersebut. Namun banyak juga pendidik yang masih banyak menggunakan metode ceramah dan pemberian tugas karena banyaknya administrasi, hal-hal yang harus diisi dalam kurikulum 2013. Seperti di sekolah SD Negeri Ciporos 03 ini, pendidik merasa kesulitan dan beban saat kurikulum 2013, karena banyak sekali yang harus dikerjakan dan banyaknya metode pengajaran di kelas, maka akhirnya masih menggunakan cara-cara atau metode yang lama atau konvensional. Dengan demikian diperlukan pengarahan metode pembelajaran IPA yang menyenangkan, salah satunya adalah metode Demontrasi. Beberapa kelebihan dari metode demontrasi ini adalah dapat menghemat waktu, menghindari verbalisme, pembelajaran menjadi lebih menarik.
\end{abstract}

Kata kunci: metode demontrasi; Pembelajaran IPA; SDN Ciporos 03 Karangpucung

ABSTRACT. Education is the learning of knowledge, skills and groups of people that are passed down from one generation to the next through training or research. Education which is supported by the name of the curriculum, in the 2013 curriculum, subjects are no longer separate, but have been integrated into one, the material is used as themes, and from that theme becomes a sub-theme. In science lessons in elementary school, starting to study in the upper classes (grades 4-6), educators are expected to be more innovative and creative in teaching, especially in science lessons where science is a natural lesson which, if only given in lectures, offers assignments and exercises only then there will be less interaction and less students understand the science lesson. However, there are also many educators who still use the lecture method and offer assignments because of the large number of administrations, things that must be filled in the 2013 curriculum.Like at Ciporos 03 Elementary School, educators find it difficult and burdensome during the 2013 curriculum, because there are so many things to do. done and the methods that are processed in class, then in the end they still use old or conventional methods. Thus, a fun science learning method is needed, one of which is the demonstration method. Some of the advantages of this demonstration method are that it can give time, avoid verbalism, and make learning more interesting.

Key words: demonstration method; science learning; SD N Ciporos 03 Karangpucung

\section{PENDAHULUAN}

Pendidikan memiliki peran sentral bagi upaya pengembangan sumber daya manusia (SDM). Adanya peran demikian isi dan proses pendidikan perlu pemutakhiran sesuai dengan kemajuan ilmu dan kebutuhan masyarakat. Implikasinya jika pada saat ini masyarakat di Indonesia menghendaki Sumber Daya Manusia (SDM) yang memiliki seperangkat kompetensi yang berstandar nasional dan internasional maka isi dan proses pendidikannya perlu di arahkan pada pencapaian kompetensi tersebut.

Peran pendidikan yang sangat penting adalah menciptakan kehidupan yang cerdas, damai, terbuka dan demokratis demi mengimbangi kemajuan ilmu di segala bidang. Kemajuan ini ditentukan oleh berbagai faktor pendidikan antara lain yaitu faktor guru. Oleh karena itu, kreativitas pendidik merupakan salah satu faktor untuk meningkatkan kualitas pendidikan nasional. Secara rinci dalam pasal 3 UU No. 20 Tahun 2003, tentang Sistem Pendidikan Nasional (SISDIKNAS) disebutkan bahwa "Pendidikan nasional berfungsi mengembangkan kemampuan dan membentuk watak serta peradaban bangsa yang bermanfaat dalam rangka mencerdaskan kehidupan bangsa, bertujuan untuk berkembangnya peserta didik agar menjadi manusia yang beriman dan bertaqwa kepada Tuhan Yang Maha Esa, berakhlak mulia, sehat, berilmu, cakap, kreatif, mandiri dan menjadi warga negara yang demokratif 
serta bertanggung jawab". Upaya mencapai tujuan pendidikan nasional diperlukan adanya pendidikan dan pembelajaran yang efektif, baik internal maupun eksternal. Efisiensi, efektivitas dan kualitas masih rendah. Indikator keberhasilan sangat minim outputnya kurang memadai (Depdiknas. 2003).

Mata pelajaran IPA(Ilmu Pengetahuan Alam) di Sekolah Dasar merupakan salah satu mata pelajaran yang menjadi materi ujian akhir nasional (UAS) dan merupakan mata pelajaran wajib yang berfungsi sebagai alat pengembangan diri peserta didik dalam berbagai kompetensi yang meliputi : kepribadian, ilmu pengetahuan, teknologi, kreatif dan kecakapan hidup. Dengan aspek tersebut peserta didik dapat tumbuh dan berkembang menjadi warga negara yang cerdas, terampil dan berkepribadian serta siap untuk ikut serta dalam menyukseskan pembangunan nasional. Ilmu Pengetahuan Alam merupakan mata pelajaran yang mengkoordinasikan berbagai disiplin ilmu sublintas mata pelajaran seperti biologi, fisika, kimia, geologi, dan antariksa. Sebenarnya ilmu pengetahuan alam dapat juga dipadukan dengan mata pelajaran lain di luar bidang kajian ilmu pengetahuan alam, karena ilmu pengetahaun alam bukan sekedar gabungan dari biologi, fisika, kimia, geologi dan antariksa tetapi juga merupakan kajian ilmu ilmiah (Mujakir. 2015).

Aspek penting dalam pokok pembelajaran IPA adalah peserta didik dapat menyadari keterbatasan pengetahuannya, membangkitkan rasa ingin tahu untuk menggali berbagai pengetahuan baru dan akhirnya dapat mengaplikasikannya dalam kehidupan berdasarkan informasi yang disampaikan pendidik. Kedudukan pendidik mempunyai arti penting dalam pendidikan yang bertolak dari tugas dan tanggung jawab pendidik yang besar untuk mencerdaskan peserta didik. Pendidik dijadikan tumpuan harapan semua orang untuk mampu menjadikan peserta didik berhasil, apakah itu didalam bidang intelektual maupun perilakunya. Hal ini sesuai dengan PP. No. 19 Tahun 2005 Bab VI Pasal 28 ayat (1) disebutkan pendidik harus memiliki kualifikasi akademik dan kompetensi sebagai agen pembelajaran, sehat jasmani dan rohani serta memiliki kemampuan untuk mewujudkan tujuan pendidikan nasional (Depdiknas. 2005)

Untuk pencapain tujuan dan fungsi tersebut, maka pembelajaran pada peserta didik sebaiknya dititik beratkan pada upaya pendidik dalam mendorong dan membiasakan diri untuk berpikir kreatif, pendidik harus memikirkan cara-cara baru agar materi pembelajaran yang diberikan kepada peserta didik mudah dipahami, dan menjadi mata pelajaran yang disukai, sehingga pada akhirnya akan membantu peserta didik mampu menyelesaikan persoalan-persoalan yang dialaminya di sekolah maupun di masyarakat.
Berdasarkan hasil survey awal dan hasil wawancara dengan pendidik di SD Negeri Ciporos 03, Kecamatan Karangpucung, Kabupaten Cilacap, bahwa pendidik masih menggunakan metode lama yaitu ceramah, latihan dan tugas. Peserta didik hanya difokuskan untuk mendengarkan, mencatat, dan mengerjakan soal-soal latihan. Selain itu juga pendidik sangat jarang menggunakan media pendukung materi, padahal materi IPA lebih banyak berkaitan dengan alam, maka dengan adanya media dan metode yang tepat akan menambah pengetahun peserta didik, meningkatkan pemahaman peserta didik terhadap materi yang diajarkan. Metode yang digunakan pendidik masih belum bisa mengaktifkan peserta didik, sehingga peserta didik banyak yang kurang memperhatikan, tidak ada siswa yang bertanya mengenai materi pembelajaran pada saat pendidik menjelaskan, peserta didik kurang aktif dan antusias dalam mengikuti pelajaran, peserta didik terlihat bosan pada saat mendengar penjelasan materi di depan kelas, sehingga diperlukan solusi untuk mengatasi masalah tersebut. Salah satu solusinya yaitu dengan melakukan pengarahan pada pendidik untuk menggunakan metode baru yang lebih membuat peserta didik aktif, kreatif, menyenangkan dan kelas menjadi hidup dengan banyaknya peserta didik yang ikut berpartispasi dalam bertanya. Metode yang dapat digunakan adalah metode demosntrasi.

\section{METODE}

Pengabdian masyarakat ini dilakukan di SD Negeri Ciporos 03, Kecamatan Karangpucung, Kabupaten Cilacap. Secara garis besar metode pembelajaran demosntrasi merupakan metode pembelajaran yang menunjukkan atau mencontohkan kepada peserta didik suatu proses terjadinya peristiwa atau benda yang diperagakan oleh pendidik Sebelum melakukan pengarahan di sekolah SD Negeri Ciporos 03, peneliti melakukan kunjungan untuk wawancara dan observasi, disamping melakukan permohonan izin pada Kepala Sekolah SD Negeri Ciporos 03 untuk melakukan kegiatan pengabdian masyarakat yaitu pengarahan pembelajaran IPA SD dengan menggunakan metode demonstrasi.

Waktu pelaksanaan dilakukan pada hari Kamis, tanggal 14 Maret 2019. Pukul 09.00-11.00 WIB. Kegiatan pengarahan pembelajaran IPA ini dihadiri oleh seluruh pendidik SD Negeri Ciporos 03, dengan mengisi absensi atau daftar hadir. Pemateri menyiapkan alat dan bahan untuk proses pengarahan pembelajaran IPA di SD Negeri Ciporos 03 tersebut.

Adapun langkah-langkah yang dilakukan dalam pengarahan penggunakan metode demonstrasi dalam pelajaran IPA untuk nanti dilakukan oleh pendidik di kelas yaitu : 
1. Pendidik menyampaikan kompetensi yang ingin dicapai

2. Pendidik menyajikan gambaran sekilas materi yang akan dibahas

3. Menyiapkan bahan atau alat yang diperlukan

4. Menunjuk salah seorang peserta didik untuk mendemonstrasikan sesuai skenario yang telah disiapkan

5. Seluruh peserta didik memperhatikan demonstrasi dan menganalisisnya

6. Tiap peserta didik mengemukakan hasil analisisnya dan juga pengalaman peserta didik didemonstrasikan

7. Pendidik membuat kesimpulan

\section{HASIL DAN PEMBAHASAN}

Demonstrasi berasal dari bahasa Yunani yaitu "methodos" yang terdiri dari "metha" yang berarti melalui atau melewati dan "hodos" yang berarti jalan atau cara. Maka metode demonstrasi adalah suatu jalan yang dilakui untuk mencapai tujuan. Dalam Kamus Besar Bahasa Indonesia, metode adalah cara kerja yang bersistem untuk memudahkan pelaksanaan kegiatan guna mencapai apa yang ditentukan. Metode adalah cara yang digunakan untuk mengimplementasikan rencana yang sudah disusun dalam kegiatan nyata agar tujuan yang telah disusun tercapai secara optimal. Metode dalam sistem pembelajaran memegang peranan yang sangat penting. Keberhasilan impelementasi pembelajaran sangat tergantung pada cara guru menggunakan metode pembelajaran. Suatu strategi pembelajaran dapat diimplementasikan melalui penggunaan metode pembelajaran (Mufarokah, A. 2009).

Metode demonstrasi adalah cara penyajian bahan pelajaran dengan memperagakan atau mempertunjukan kepada peserta didik suatu proses, situasi atau benda tertentu yang sedang dipelajari baik sebenarnya atau tiruan yang sering disertai penjelasan lisan. Metode demontrasi adalah metode mengajaryang sangat efektif, karena dapat membantu peserta didik untuk melihat secara langsung proses terjadinya sesuatu. Dapat disimpulkan bahwa metode demonstrasi adalah metode mengajar dimana seorang pendidik atau orang lain yang sengaja diminta peserta didik sendiri memperlihatkan kepada seluruh peserta didik di dalam kelas, suatu kaifiyah melakukan sesuatu (Djamarah, S.B. 2006).

Agar tujuan pembelajaran dengan menggunakan metode demonstrasi dapat tercapai dapat menggunakan strategi yaitu: 1) merumuskan dengan jelasjeniskecakapanatauketerampilanyangdiperoleh setelah demontrasi dilakukan; 2) menentukan peralatan yang digunakan, kemudian diuji coba terlebih dahulu agar pelaksanaan demonstrasi tidak mengalami kegagalan, 3) menetapkan prosedur yang dilakukan dan melakukan percobaan sebelum demonstrasi dilakukan; 4) menentukan durasi pelaksanaan demonstrasi; memberikan kesempatan kepada peserta didik untuk memberikan komentar pada saat maupun sesudah demonstrasi; 6) meminta peserta didik untuk mencatat hal-hal yang dianggap perlu; 7) menetapkan rencana untuk menilai kemajuan peserta didik (Huda, M. 2013).

Menurut Huda (2013:230) dalam Trisnawaty (2017), beberapa keunggulan dengan penggunaan metode demonstrasi adalah : a) membuat pengajaran menjadi lebih jelas dan konkrit; b) memusatkan perhatian peserta didik; c) lebih mengarahkan proses belajar peserta didik pada materi yang sedang dipelajari; d) lebih melekatkan pengalaman dan kesan sebagai hasil pembelajaran dalam diri peserta didik; e) membuat peserta didik lebih mudah memahami apa yang dipelajari; f) membuat proses pengajaran lebih menarik; g) merangsang peserta didik untuk aktif mengamati dan menyesuaikan antara teori dengan kenyataan; h) membantu peserta didik memahami dengan jalannya suatu proses atau kerja suatu benda; i) memudahkan berbagai jenis penjelasan; j) memperbaiki kesalahan yang terjadi dari hasil ceramah melalui pengamatan langsung dan contoh konkrit dengan menghadirkan objek sesungguhnya.

Dalam kegiatan pengabdian kepada masyarakat ini, dimana dilakukan pengarahan pada pendidik di SD Negeri Ciporos 03 menunjukkan hasil yang memuaskan dimana para pendidik menjadi termotivasi dalam melakukan pembelajaran menggunakan metode demonstrasi. Di sekolah tersebut juga terdapat KIT IPA yang disediakan untuk pendidik saat pembelajaran IPA di kelas, namun sayang tidak pernah digunakan karena malas dan merepotkan, namun dengan kegiatan pengarahan ini pendidik menjadi lebih temrotivasi, ditambah mereka jadi tahu tentang cara-cara penggunaan alat KIT IPA, menyebutkan namanama KIT IPA, dan cara-cara menyimpan KIT IPA tersebut. Dengan demikian pendidik lebih senang menggunakan KIT IPA tersebut dipadukan dengan metode demontrasi sehingga menjadikan kelas yang lebih hidup. Setelah pembelajaran menggunakan metode demonstrasi, pendidik bisa memberikan tugas pada peserta didik untuk melakukan praktek sesuai demo yang telah diajarkan di depan kelas, lalu membuat analisis di buku latihan dan maju ke depan kelas untuk mempresentasikan hasil analisisnya tersebut. Dengan demikian akan terlihat antusiasme peserta didik dan menjadikan satu kelebihan lagi yaitu peserta didik dilatih berani maju ke depan kelas dan mengeluarkan suara dalam mempresentasikan hasil analisisnya. Guru bisa membagi peserta didik 
menjadi beberapa kelompok agar lebih efektif, dan peserta didik belajar untuk bekerjasama dalam tim. Selain itu dalam pengarahan ini pendidik diajarkan tata cara menghindari kerusakan yang terjadi pada KIT IPA, karena usia anak Sekolah Dasar masih senang bermain, senang bereksplorasi sehingga perlu panduan-panduan dan arahan yang membuat peserta didik paham dalam penggunan KIT IPA, dalam mengetahui apa saja KIT IPA tersebut saat pembelajaran IPA dipadu metode demonstrasi.

Metode demontrasi ini juga bisa dilakukan diluar kelas atau outdor class sehingga bisa bertemu dengan alam dan lebih menyenangkan, tidak tegang seperti saat di dalam kelas. Menurut Rakhmat (2007:39) dalam Rifai (2017), metode demontrasi merupakan pendekatan dalam proses belajar mengajar yang dapat memberikan pengaruh tiga hal yaitu : a) maksimalisasi pengaruh tubuh terhadap jiwa; b) maksimalisasi pengaruh jiwa terhadap proses psikofisik dan psikososial, serta bimbingan kearah pengalaman mistik. Hal ini berarti bahwa saat pembelajaran di luar kelas, jiwa peserta didik bisa maksimal, bisa lebih berinteraksi dengan sesame dan alam dan lebih mendekatkan jiwa peserta didik terhadap Tuhan, karena dalam IPA(Ilmu Pengetahuan Alam), menyadarkan bahwa di dunia ini tidak hanya ada manusia tapi ada makhluk lain yang sama-sama hidup dan tinggal.

\section{SIMPULAN}

Berdasar hasil dan pembahasan di atas, dapat disimpulkan bahwa metode demonstrasi adalah salah satu metode yang baik dan tepat digunakan dalam pembelajaran IPA di SD. Tiap SD sudah difasilitasi dengan adanya KIT IPA, maka dengan adanya kegiatan pengarahan ini menjadikan pendidik lebih semangat dna temrotivasi dalam pembelajaran yang awalnya hanya menggunakan metode ceramah dan penugasan saja. Pendidik mengetahui apa saja manfaat KIT IPA, nama-nama alat dalam KIT IPA, cara penggunaannya dan tata cara menyimpan, menjaga dari kerusakan KIT IPA tersebut.

\section{DAFTAR PUSTAKA}

Djamarah, S.B. 2006. Strategi Belajar Mengajar. Rineka Cipta: Jakarta).

Depdiknas. 2003. UU No. 20 tentang Sistem Pendidikan Nasional (SISDIKNAS). Depdiknas: Jakarta

Depdiknas. 2005. Peraturan Pemerinbtah Republik Indonesia Nomor 19 Tahun 2005 tentang Standar nasional pendidikan. Depdiknas: Jakarta

Huda, M. 2013: 232. Model-Model Pengajaran dan Pembelajaran. Pustaka Belajar: Yogyakarta

Mufarokah, A. 2009. Strategi Belajar Mengajar. Teras :Yogyakarta.

Mujakir. 2015. Kreativitas Guru dalam Pembelajaran IPA di Sekolah Dasar. Lantanida Journal. Vol. 3 , No. 1

Rifai. 2017. Penerapan Metode Demonstrasi untuk Meningkatkan Hasil Belajar Pendidikan Agama Kristen Materi Pembelajaran Sakramen Perjamuan Kudus VIII SMP Negeri 17 Surakartsa, Tahun 2015/2016. DINAMIS (Jurnal Teologi dan Pendidikan Kristiani) Vol. 1 No. 2: 172-192.

Trisnawaty, F. 2017. Peningkatan Hasil Belajar IPA Melalui Penggunaan Metode Demonstrasi Pada Siswa Kelas 4 SD. Setya Widya. Vol. 33. No. 1: 37-44. 